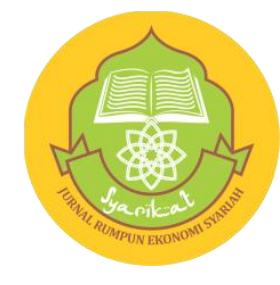

SYARIKAT : Jurnal Rumpun Ekonomi Syariah

Volume 2 Nomor 1, Juni 2019

p-ISSN 2654-3923

e-ISSN 2621-6051

\title{
REALISASI CORPORATE SOCIAL RESPONSIBILITY: SEBUAH TINJAUAN DISTRIBUSI PENDAPATAN DALAM ISLAM (Studi Kasus: PT. Pertamina (persero) RU II Dumai)
}

\author{
Risman Hambali' ${ }^{1}$, Nurul Huda ${ }^{2}$ * \\ * Sekolah Tinggi Agama Islam Negeri (STAIN) Bengkalis \\ Jl. Lembaga, Senggoro, Kec. Bengkalis, Kabupaten Bengkalis, Riau 28714 \\ e-mail: rismanhambaliselari@gmail.com,nurulhuda@kampusmelayu.ac.id
}

\begin{abstract}
Abstrak: Tanggung jawab sosial perusahaan/Corporate Social Responsibility (CSR) merupakan satu dari beberapa tanggung jawab perusahaan kepada pemangku kepentingan (stakeholders). Tanggung jawab sosial perusahaan juga merupakan kewajiban perusahaan untuk perumusan kebijakan, mengambil keputusan dan melaksanakan tindakan yang memberikan manfaat kepada masyarakat. Pentingnya distribusi harta kekayaan dalam ekonomi Islam tidak berarti tidak memperhatikan keuntungan yang diperoleh dari produksi. Maka dalam distribusi, Islam telah membuat beberapa prinsip dasarnya, yaitu sebagai berikut; 1) Prinsip keadilan atau pemerataan, 2) Prinsip persaudaraan atau kasih sayang, 3) Prinsip jaminan sosial. Tujuan yang ingin dicapai dalam penelitian ini adalah; 1) Mengidentifikasi dan menganalisa dampak CSR PT. Pertamina (Persero) RU II Dumai periode 2011-2015 terhadap masyarakat. 2) Menganalisa kesesuaian antara informasi terkait dengan tanggung jawab sosial yang dilaksanakan oleh PT. Pertamina (Persero) RU II Dumai periode 2011-2015 dengan konsep dan karakteristik realisasi CSR berdasarkan distribusi pendapatan dalam Islam. Realisasi Corporate Social Responsibility/CSR Pertamina (Persero) RU II Dumai dalam Tinjauan Distribusi Pendapaatan dalam Islam sebagai berikut: 1). Realisasi CSR Pertamina Dumai berdampak positif terhadap kehidupan masyarakat. 2). Informasi-inforrmasi terkait dengan tanggung jawab sosial yang dilaksanakan oleh Pertamina Dumai periode 2011-2015 tidak sepenuhnya sesuai dengan konsep dan karakteristik realisasi CSR berdasarkan distribusi pendapatan dalam Islam.
\end{abstract}

Kata Kunci : Tanggungjawab Sosial Perusahaan, Distribusi Pendapatan 


\section{PENDAHULUAN}

Menurut (Rahman, 2009) Corporate Social Responsibility menjadi tuntutan tak terelakkan seiring dengan bermunculannya tuntutan komunitas terhadap korporat. Korporat sadar bahwa keberhasilannya dalam mencapai tujuan bukan hanya dipengaruhi oleh faktor internal melainkan juga oleh komunitas yang berada di sekelilingnya. Ini artinya, telah terjadi pergeseran hubungan antara korporat dan komunitas. Korporat yang semula memposisikan diri sebagai pemberi donasi melalui kegiatan charity dan phylantrophy, kini memposisikan komunitas sebagai mitra yang turut andil dalam kelangsungan eksistensi korporat.Dalam prakteknya di lapangan, suatu kegiatan disebut CSR ketika memiliki sejumlah unsur berikut:

1. Continuity and Sustainability atau berkesinambungan dan berkelanjutan merupakan unsur vital dari CSR. Suatu kegiatan amal yang berdasarkantrend ataupun insidental, bukanlah CSR. CSR adalah suatu mekanisme kegiatan yang terencanakan, sistematis dan dapat dievaluasi.

2. Community Empowerment atau pemberdayaan komunitas. Salah satu indikasi dari suksesnya sebuah program CSR adalah adanya kemandirian yang lebih pada komunitas, dibandingkan dengan sebelum program CSR hadir.

3. Two Ways atau program CSR bersifat dua arah. Korporat bukan lagi berperan sebagai komunikator semata, tetapi juga harus mampu mendengarkan aspirasi dari komunitas. Ini dapat dilakukan dengan need assesment, yaitu sebuah survei untuk mengetahui need, desires, interest dan wants dari komunitas.

Islam memandang, bahwa tanggung jawab pemerintah bukan terbatas pada keamanan dalam negeri dan sistem keamanan yang mempunyai kekuatan antisipatif dari serangan luar. Tetapi pertanggungjawaban pemerintah ini harus merupakan bagian dari program pencapaian masyarakat ideal; makmur dan adil. Keadilan dalam masyarakat tidak mungkin tercipta tanpa keterlibatan pemerintah dalam membela yang lemah dan memberikan jaminan sosial kepada mereka, termasuk yang menyangkut masalah perekonomian. Distribusi harta kekayaan merupakan masalah yang sangat penting dalam mewujudkan pemerataan ekonomi masyarakat. Pentingnya distribusi harta kekayaan dalam ekonomi Islam tidak berarti tidak memperhatikan keuntungan yang diperoleh dari produksi. Maka dalam distribusi,(Mujahidin, 2014) Islam telah membuat beberapa prinsip dasarnya, yaitu sebagai berikut:

1. Prinsip keadilan atau pemerataan,

2. Prinsip persaudaraan atau kasih sayang,

3. Prinsip jaminan sosial.

Di Kotamadya Dumai terdapat sebuah perusahaan yang bergerak dalam bidang pengolahan bahan bakar yaitu PT. Pertamina (Persero) RU II Dumai yang tentunya hal ini bisa dimanfaatkan untuk dijadikan sebagai peluang dalam percepatan pembangunan, baik pembangunan ekonomi, sarana dan prasarana dan peningkatan kualitas Sumber Daya Manusia melalui realisasi CSR.

\section{TINJAUAN PUSTAKA}

\section{Corporate Social Responsibility}

\section{a. Konsep Tanggung Jawab Sosial Perusahaan}

Sebenarnya definisi tanggung jawab sosial perusahaan/ Corporate Social Responsibility (CSR)sangatlah beragam, tergantung pada visi dan misi korporat yang disesuaikan dengan needs, desire, 
wants dan interest komunitas. Berikut adalah beberapa definisi CSR (Rahman, 2009):

1) Melakukan tindakan sosial (termasuk kepedulian terhadap lingkungan hidup, lebih dari batas-batas yang dituntut peraturan Undang-Undang.

2) Komitmen usaha untuk bertindak secara etis, beroperasi secara legal dan berkontribusi untuk kepentingan ekonomi bersamaan dengan peningkatan kualitas hidup karyawan dan keluarganya, komunitas lokal dan masyarakat yang lebih luas

3) Komitmen bisnis untuk berkontribusi dalam pembangunan ekonomi berkelanjutan, bekerja dengan karyawan perusahaan, keluarga karyawan tersebut, berikut komunitas setempat (local) dan masyarakat secara keseluruhan dalam rangka meningkatkan kualitas hidup.

Dari berbagai definisi CSR yang ada, maka dapat disimpulkan bahwa Corporate Social Responsibility (CSR) adalah suatu kepatuhan dan kebijakan yang disusun secara sistematis dan dibuktikan dengan tindakan nyata dari perusahaan dalam pendistribusiannya akibat dari operasional yang dilakukan demi terciptanya tatanan kehidupan yang baik berdasarkan ketentuan hukum.

\section{b. Sejarah Corporate Social \\ Responsibility}

Dalam Kode Hammurabi (salah satu contoh dari kode/ aturan hukum kuno 1700-an SM) yang berisikan 282 pasal disebutkan bahwa hukuman mati diberikan kepada orang-orang yang menyalahgunakan izin penjualan minuman, pelayanan yang buruk dan melakukan pembangunan gedung di bawah standar sehingga menyebabkan kematian orang lain.

CSR juga muncul sejak tahun 1800-an

yang lebih dikenal dengan nama
Occupational Social Worker, Social Work in The Workplace, Employee Assistance yang bisa juga disebut dengan Pekerjaan Sosial Industri (PSI). Inggris, Jerman dan Amerika Serikat telah melakukan PSI sejak tahun 1890, sedangkan Prancis sejak tahun 1920. Di dalam PSI inilah terdapat berbagai bentuk program CSR baik berupa strategi maupun program pengembangan masyarakat. Seiring berjalannya waktu, CSR pun turut berkembang dengan pesat (Sindhudiptha danYasa, 2013).

\section{c. Indikator keberhasilan dan Manfaat CSR}

Indikator keberhasilan CSR dapat dilihat dari dua sisi perusahaan dan masyarakat. Dari sisi perusahaan, citranya harus semakin baik dimata masyarakat. Sementara itu dari sisi masyarakat harus ada peningkatan kualitas hidup karenanya, penting bagi perusahaan melakukan evaluasi untuk mengukur keberhasilan program CSR, baik secara kuantitatif maupun kualitatif. Satu hal yang perlu diingat, salah satu ukuran penting keberhasilan CSR adalah jika masyarakat yang dibantu bisa mandiri, tidak selalu bergantung pada pertolongan orang lain (Marbun, 2014).

\section{d. Teori-Teori Corporate Social Responsibility}

Ada beberapa alasan perusahaan untuk melakukan atau tidak melakukan pengungkapan CSR. Alasan-alasan tersebut dapat dijelaskan menggunakan Agency Theory, Legitimacy Theory dan Stakeholders Theory. Selain dari ketiga teori tersebut, masih ada teori-teori yang berkaitan dengan pelaksanaan CSR, antara lainPolitical Economy Theory, Teori Komunikasi Aksi Habermas, Sharia Enterprise Theory(Koto dan Saputra, 2014).

e. Tujuan dan Manfaat Corporate Social Responsibility

Tujuan CSR adalah untuk pemberdayaan masyarakat, bukan 
memperdayai masyarakat. Pemberdayaan bertujuan mengkreasikan masyarakat mandiri. CSR bukan hanya usaha mendapatkan izin sosial dari masyarakat untuk mengamankan operasional perusahaan atau untuk mengurangi kerugian lingkungan dari aktivitas usahanya, namun CSR merupakan upaya untuk meningkatkan kualitas hidup dari stakeholders, sesuai dengan prioritasnya, atau dengan kata lain upaya untuk meningkatkan mutu hidup bersama, maju bersama seluruh stakeholder.Sedikitnya ada lima manfaat yang terkandung dalam CSR terhadap perusahaan yaitu(Faroid dan Murtadlo, 2014):

1) Menigkatkan profitabilitas dan kinerja finansial yang lebih kokoh, misalnya melalui efisiensi lingkungan,

2) Meningkatkan akuntabilitas assessment dan komunitas investasi,

3) Mendorong komitmen karyawan, karena mereka diperhatikan dan dihargai,

4) Menurunkan kerentanan gejolak dengan komunitas,

5) Mempertinggi reputasi dan corporate branding.

f. Dasar Hukum Corporate Social Responsibility

Terdapat 4 (empat) peraturan yang mewajibkan perusahaan tertentu untuk menjalankan tanggungjawab sosial perusahaan dan satu acuan (guidance) ISO 26000 sebagai referensi dalam menjalankan CSR, yaitu:

1) Keputusan Menteri Negara Badan Usaha Milik Negara Nomor PER05/MBU/2007Tentang Program Kemitraan Badan Usaha Milik Negara Dengan Usaha Kecil Dan Program Bina Lingkungan.

2) Undang-Undang Republik Indonesia Nomor 40 Tahun 2007 Tentang Perseroan Terbatas.
3) Undang-Undang Republik Indonesia Nomor 25 Tahun 2007 Tentang Penanaman Modal.

4) Undang-Undang Republik Indonesia Nomor 22 Tahun 2001 Tentang Minyak dan Gas Bumi.

5) Guidance ISO 26000.

Selain itu, CSR di Indonesia telah diatur sejak lama, hal ini dibuktikan dengan banyaknya peraturan yang mengatur tentang CSR, baik secara umum maupun secara khusus. Sehingga pengaturan CSR di Indonesia telah memiliki konsekuensi secara yuridis dan sanksi yang tegas dalam pelaksanaannya. Adapun peraturanperaturan tersebut yang telah penulis rangkum, antara lain:

1) Undang-Undang Dasar Tahun 1945, Pasal 33

2) Undang-Undang Republik Indonesia Nomor 40 Tahun 2007 Tentang Perseroan Terbatas, Pasal 74

3) Undang-Undang Dasar HAM Nomor 39 Tahun 1999

4) Undang-Undang Republik Indonesia Nomor 19 Tahun 2003 Tentang Badan Usaha Milik Negara

5) Undang-Undang Republik Indonesia Nomor 25 Tahun 2007 Tentang Penanaman Modal, Pasal 15, 16, 17 dan 34

6) Undang-Undang Nomor 23 Tahun 1997 Tentang Pengelolaan Lingkungan Hidup, pada Pasal 6 Ayat 1 dan 2, Pasal 16 Ayat 1, dan Pasal 17 Ayat 1.

7) Undang-Undang Nomor 13 Tahun 2003 Tentang Ketenagakerjaan

8) Undang-Undang Republik Indonesia Nomor 22 Tahun 2001 Tentang Minyak dan Gas Bumi, Pasal 2 dan 3 huruf (f).

\section{g. Corporate Social Responsibility dalam Pandangan Islam}

Dalam perspektif Islam, CSR merupakan realisasi dari konsep ajaran 
ihsan sebagai puncak dari ajaran etika yang sangat mulia. Ihsan merupakan melaksanakan perbuatan baik yang dapat memberikan kemanfaatan kepada orang lain demi mendapatkan ridho Allah swt. Disamping itu, CSR merupakan implikasi dari ajaran kepemilikan dalam Islam. Allah swt adalah pemilik mutlak (haqiqiyah) sedangkan manusia hanya sebatas pemilik sementara (temporer) yang berfungsi sebagai penerima amanah. Allah swt berfirman:

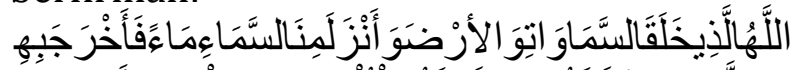

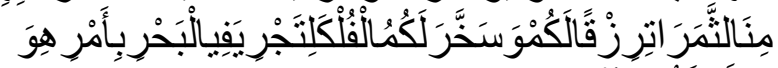

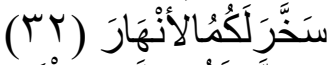

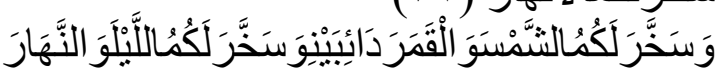

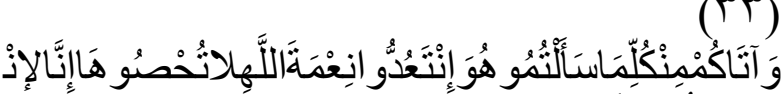

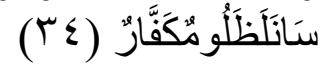
32. "Allah-lah yang telah menciptakan langit dan bumi dan menurunkan air hujan dari langit, kemudian Dia mengeluarkan dengan air hujan itu berbagai buah-buahan menjadi rezki untukmu dan Dia telah menundukkan bahtera bagimu supaya bahtera itu berlayar di lautan dengan kehendak-Nya dan Dia telah menundukkan (pula) bagimu sungaisungai".

33. "Dan Dia telah menundukkan (pula) bagimu matahari dan bulan yang terus menerus beredar (dalam orbitnya) dan telah menundukkan bagimu malam dan siang".

34. "Dan Dia telah memberikan kepadamu (keperluanmu) dan segala apa yang kamu mohonkan kepada-Nya. Dan jika kamu menghitung nikmat Allah, tidaklah dapat kamu menghitungnya. Sesungguhnya manusia itu, sangat zalim dan sangat mengingkari (nikmat Allah)".

CSR ternyata selaras dengan pandangan Islam tentang manusia sehubungan dengan dirinya sendiri dan lingkungan sosial, dapat dipresentasikan dengan empat aksioma yaitu kesatuan/ tauhid, keseimbangan (equilibrium), kehendak bebas (free will) dan tanggung jawab (responsibility) (Darmawati, 2014).

Sebenarnya konsep CSR di dalam Islam telah diajarkan dengan adanya pelaksanaan zakat. Zakat yang didistribusikan merupakan kewajiban bagi setiap Muslim dengan tujuan kebahagiaan dan kesejahteraan bersama.

Zakat (yaitu pajak yang diberikan kaum Muslimin) dimaksudkan untuk kaum miskin (fuqara) Muslimin, untuk merebut hati mereka, membebaskan budak dan tawanan perang, membantu mereka yang terjerat utang, mereka yang di jalan Allah dan Allah Maha Mengetahui. Seperti tercantum dalm Al-Qur'an:

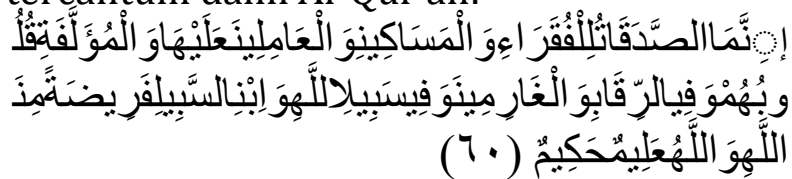

"Sesungguhnya zakat-zakat itu hanyalah untuk orang-orang faqir, orang-orang miskin, pengurus-pengurus zakat, para mu'allaf yang dibujuk hatinya, untuk (memerdekakan) budak, orang-orang yang berhutang, untuk jalan Allah dan untuk mereka yuang sedang dalam perjalanan sebagai suatu ketetapan yang diwajibkan Allah, dan Allah Maha Mengetahui lagi Maha Bijaksana.

Menurut (Mujahidin, 2014) bangunan ekonomi Islam didasarkan atas lima nilai universal, yakni: Tauhid (keimanan), 'Adl (keadilan), Nubuwwah (Kenabian), Khilafah (pemerintah) dan Ma'ad (hasil). Kelima nilai ini menjadi dasar inspirasi untuk menyusun teori-teori ekonomi Islam.

\section{Distribusi Pendapatan Dalam Islam}

\section{a. Definisi dan Konsep}

Distribusi pendapatan dalam Islam merupakan penyaluran harta yang ada, baik dimiliki oleh pribadi atau umum (public) kepada pihak yang berhak menerima yang ditujukan untuk meningkatkan kesejahteraan masyarakat sesuai dengan syariat. Fokus dari distribusi pendapatan dalam Islam adalah proses 
pendistribusiannya. Secara sederhana bisa digambarkan, kewajiban menyisihkan sebagian harta bagi pihak surplus (berkecukupan) diyakini sebagai kompensasi atas kekayaannya dan di sisi lain merupakan insentif (perangsang) untuk kekayaan pihak defisit (berkekurangan) (Rozalinda, 2015).

\section{b. Tujuan}

Distribusi sama dengan produksi dan konsumsi yang mempunyai tujuan, antara lain (Mujahidin, 2014):

1) Menjamin terpenuhinya kebutuhan dasar masyarakat

2) Mengurangi ketidaksamaan pendapatan dan kekayaan dalam masyarakat

3) Untuk mensucikan jiwa dan harta

4) Untuk membangun generasi yang unggul

5) Untuk mengembangkan harta

Tujuan distribusi pendapatan dalam ekonomi Islam antara lain (Rozalinda, 2015):

1) Tujuan dakwah

2) Tujuan pendidikan

3) Tujuan sosial

4) Tujuan ekonomi

\section{c. Landasan Hukum}

Landasan hukum distribusi dalam Islam bersumber dari Al-Qur'an dan Hadis, di antaranya:

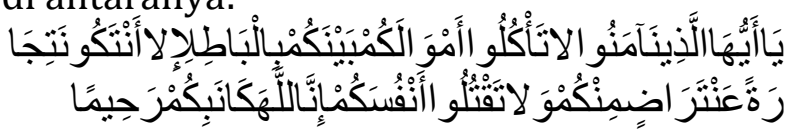

( $Y q)$

"Hai orang-orang yang beriman, janganlah kamu saling memakan harta sesamamu dengan jalan yang bathil, kecuali dengan jalan perniagaan yang berlaku dengan suka sama-suka di antara kamu, dan janganlah kamu membunuh dirimu. Sesungguhnya Allah adalah Maha Penyayang kepadamu."

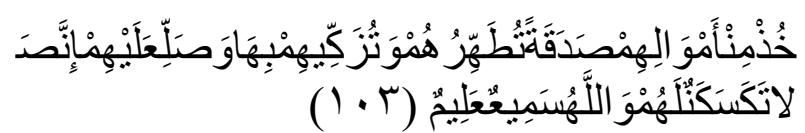

"Ambillah zakat dari sebagian harta mereka, dengan zakat itu kamu membersihkan dan mensucikan mereka dan berdoalah untuk mereka.Sesungguhnya doa kamu itu (menjadi) ketenteraman jiwa bagi mereka, dan Allah Maha Mendengar lagi Maha Mengetahui."

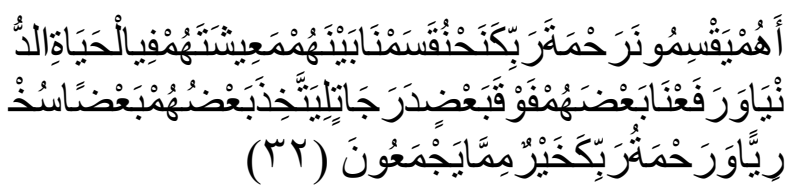

"Apakah mereka yang membagi-bagi Rahmat Tuhanmu? Kami telah menentukan antara mereka penghidupan mereka dalam kehidupan dunia dan Kami telah meninggikan sebagian mereka atas sebagian yang lain beberapa derajat, agar sebagian mereka dapat mempergunakan sebagian yang lain. Dan Rahmat Tuhanmu lebih baik dari apa yang mereka kumpulkan."

\section{d. Prinsip}

Dalam distribusi menurut (Mujahidin, 2014), Islam telah membuat beberapa prinsip dasar, yaitu:

1) Prinsip keadilan atau pemerataan

2) Prinsip persaudaraan atau kasih sayang

3) Prinsip jaminan sosial

e. Corporate Social Responsibility dan Distribusi Pendapatan dalam Islam

Pengaturan realisasi CSR yang baik dan benar bisa merujuk pada pola realisasi distribusi pendapatan dalam Islam. Islam mengajarkan umatnya untuk tidak hidup bermewah-mewahan dan salinng berbagi dari pihak yang berkecukupan kepada pihak yang berkekurangan. Konsep yang paling mendominasi untuk diadobsi oleh realisasi CSR di dalam Islam adalah zakat. Baitul mal membagikan kepada orang yang membutuhkan untuk meringankan masalah hidup orang lain dengan cara memberi bantuan langsung ataupun tidak langsung.

Pola-pola realisasi harta yang telah diajarkan oleh Islam memberikan dampak positif dalam mengatur tatanan kehidupan 
sosial. Dengan demikian untuk meningkatkan efektifitas realisasi CSR yang baik dan benar, maka perusahaanperusahaan baik swasta maupun BUMN yang ada di negeri ini sudah saatnya menerapkan sistem realisasi yang telah dicontohkan di dalam ajaran dan tuntunan Islam dengan konsep distribusi pendapatan dalam Islam.

\section{METODE}

\section{Pendekatan Penelitian}

Metode penelitian ini adalah penelitian kualitatif. Penelitian ini merupakan penelitian lapangan (field research). Dengan kata lain, peneliti langsung ke lapangan untuk mengambil data, melihat realisasi CSR PT. Pertamina (Persero) RU II Dumai.

\section{Informan atau Populasi dan Sampel Penelitian}

Informan dalam penelitian ini adalah Divisi CSR PT. Pertamina (Persero) RU II Dumai sebagai pelaksana CSR, Pemerintah Kotamadya Dumai dalam hal ini Camat/ Sekcam dan Lurah di tiga Kecamatan yaitu Dumai Timur, Dumai Selatan dan Dumai Barat sebagai pemegang amanat UndangUndang dan pembuat kebijakan publik serta masyarakat dan beberapa orang tokoh masyarakat di tiga Kecamatan sebagai penerima manfaat dari realisasi CSR perusahaan.

Populasi dari penelitian ini adalah realisasi CSR Pertamina (Persero) RU II Dumai se-Kotamadya Dumai. Jenis sampel dalam penelitian ini adalah sampel bertujuan (purposive sampling).

Idealnya penelitian ini dilakukan pada seluruh Perseroan Terbatas (PT) yang beroperasi di Kotamadya Dumai, namun karena keterbatasan waktu dan biaya penelitian, maka sampel penelitian ini dilakukan pada PT. Pertamina (Persero) RU II Dumai di tiga Kecamatan periode tahun 2011-2015 yaitu Kecamatan Dumai Timur,
Kecamatan Dumai Selatan dan Kecamatan Dumai Barat, dengan total jumlah penduduk sebanyak 631.336 orang. Namun di Kecamatan Dumai Barat hanya di tahun 2011, karena di tahun berikutnya terjadi pemekaran Kecamatan dan bergabung menjadi Kecamatan Dumai Selatan. Pengambilan sampel ini dengan alasan karena operasional dan perumahan karyawan PT. Pertamina (Persero) RU II Dumai berada di tiga Kecamatan tersebut. Adapun jumlah penduduk untuk tiga Kecamatan tersebut seperti terlihat pada tabel berikut ini: 
Tabel 1 : Jumlah Penduduk Kecamatan Dumai Timur Tahun 2011-2015

\begin{tabular}{|c|c|}
\hline \multicolumn{2}{|c|}{ KECAMATAN DUMAI TIMUR } \\
\hline TAHUN & JUMLAH PENDUDUK \\
\hline 2011 & 98.189 \\
\hline 2012 & 64.543 \\
\hline 2013 & 61.951 \\
\hline 2014 & 58.544 \\
\hline 2015 & 58.489 \\
\hline JUMLAH & $\mathbf{3 4 1 . 7 1 6}$ \\
\hline
\end{tabular}

Tabel 2 :Jumlah Penduduk Kecamatan Dumai Selatan Tahun 2011-2015

\begin{tabular}{|c|c|}
\hline \multicolumn{2}{|c|}{ KECAMATAN DUMAI SELATAN } \\
\hline TAHUN & JUMLAH PENDUDUK \\
\hline 2011 & $\begin{array}{l}\text { Pra pemekaran Kecamatan (masih } \\
\text { berada di Kecamatan Dumai Barat) }\end{array}$ \\
\hline 2012 & 51.013 \\
\hline 2013 & 49.492 \\
\hline 2014 & 46.358 \\
\hline 2015 & 45.354 \\
\hline JUMLAH & $\mathbf{1 9 2 . 2 1 7}$ \\
\hline
\end{tabular}

Tabel 3 : Jumlah Penduduk Kecamatan Dumai Barat Tahun 2011

\begin{tabular}{|c|c|}
\hline \multicolumn{2}{|c|}{ KECAMATAN DUMAI BARAT } \\
\hline TAHUN & JUMLAH PENDUDUK \\
\hline 2011 & 97.403 \\
\hline
\end{tabular}

Agar perolehan sampel lebih akurat, maka digunakan rumus yang dikemukakan oleh Issac dan Michael sebagai berikut:

$$
s=\frac{\lambda^{2} \cdot \mathrm{N} \cdot \mathrm{P} \cdot \mathrm{Q}}{d^{2}(\mathrm{~N}-1)+\lambda^{2} \cdot \mathrm{P} \cdot \mathrm{Q}}
$$

$\lambda^{2}$ dengan $\mathrm{dk}=1$, taraf kesalahan bisa $1 \%$, $5 \%, 10 \%$.

$\mathrm{P}=\mathrm{Q}=0.5 \mathrm{~d}=0.05 . s=$ jumlah sampel Keterangan:

$s=$ Jumlah sampel

$\lambda^{2}=$ Chi Kuadrat yang harganya tergantung derajat kebebasan 
dan tingkat kesalahan. Untuk derajat kebebasan 1 dan kesalahan $5 \%$ harga Chi Kuadrat $=3,841$. Harga Chi Kuadrat kesalahan $1 \%=6,634$ dan $10 \%=2,706$. (Dalam hal ini penulis mengambil tingkat kesalahan 10\%).

$\mathrm{N}=$ Jumlah populasi

$\mathrm{P}=$ Peluang benar

$\mathrm{Q}=$ Peluang salah

$\mathrm{d}=$ Perbedaan antara rata-rata sampel dengan rata-rata populasi. Perbedaan bisa 0,01 ; 0,05 dan 0,10 .

Berdasarkan formulasi tersebut, dari jumlah populasi sebanyak 631.336, maka banyaknya unit dapat dihitung sebagai berikut:

$\mathrm{N}=\quad$ Jumlah seluruh populasi $\mathrm{n}=\quad$ Jumlah masing-masing unit populasi.

$$
\begin{gathered}
S \\
=\frac{2,706 \times 631.336 \times 0,5 \times 0,5}{0.05^{2}(631.336-1)+2,706 \times 0,5 \times 0,5} \\
S=\frac{427.098,8}{1578,3375+0,6765} \\
S=\frac{427.098,8}{1579,014} \\
S=270,48
\end{gathered}
$$

Dibulatkan menjadi 270 orang.

Penentuan jumlah sampel untuk masing-massing kecamatan, dihitung secara proporsional dengan menggunakan rumus:

$$
\mathrm{s}=\frac{n}{N} x S
$$

Keterangan:

$\mathrm{s} \quad=\quad$ Jumlah sampel setiap unit secara proporsi

$\mathrm{S} \quad=\quad$ Jumlah seluruh sampel yang didapatkan

Maka berdasarkan rumus Isaac dan Michael, diperoleh jumlah sampel masingmasing kecamatan seperti pada tabel di bawah ini:

\section{Tabel 4: Jumlah Sampel Setiap Kecamatan}

\begin{tabular}{|c|l|c|c|}
\hline NO & KECAMATAN & UNIT POPULASI & UNIT SAMPEL \\
\hline 1 & Dumai Timur & 341.716 & 146 \\
\hline 2 & Dumai Selatan & 192.217 & 82 \\
\hline 3 & Dumai Barat & 97.403 & 42 \\
\hline \multicolumn{2}{|c|}{ JUMLAH } & $\mathbf{6 3 1 . 3 3 6}$ & $\mathbf{2 7 0}$ \\
\hline
\end{tabular}

\section{Instrumen Penelitian}

Oleh sebab itu, yang menjadi instrumen di dalam penelitian ini adalah:

1) Wawancara (interview)

2) Kuesioner

3) Observasi

4) Dokumentasi.

\section{Analisa Data}

Di dalam penelitian ini penulis menggunakan teknik analisa data dengan cara:
1) Mengorganisir Data

2) Data Reduction

\section{HASIL}

Dalam prinsip ekonomi Islam yang diharuskan adalah menjadi tidak hidup bermewah-mewahan, tidak bekerja pada pekerjaan yang dilarang, membayar zakat dan menjauhi riba merupakan rangkuman dari akidah, akhlak dan syariah Islam yang menjadi rujukan dalam membangun sistem 
ekonomi Islam. Sebagaimana keterangan dalam ayat Al-Qur'an di bawah ini:

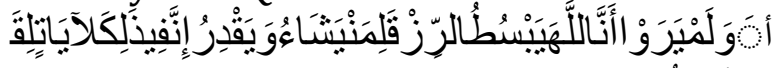

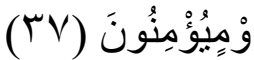

"Dan Apakah mereka tidak memperhatikan bahwa sesungguhnya Allah melapangkan rizki bagi siapa yang dikehendaki-Nya dan Dia (pula) yang menyempitkan (rizki itu). Sesungguhnya pada yang demikian itu benar-benar terdapat tanda-tanda (kekuasaan Allah) bagi kaum yang beriman".

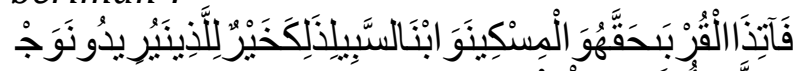

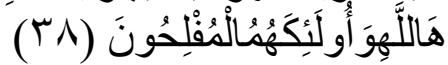
"Maka berikanlah kepada kerabat yang terdekat akan haknya, demikian (pula) kepada faqir miskin dan orang-orang yang dalam perjalanan. Itulah yang lebih baik bagi orang-orang yang mencari keridhaan Allah dan mereka itulah orang-orang beruntung".

Realisasi CSR PT. Pertamina (Persero) RU II Dumai tidak sepenuhnya sesuai dengan konsep distribusi pendapatan dalam Islam. Hal ini terbukti dari berbagai respon masyarakat setempat terhadap pernyataan kuesioner yang telah disebarkan maupun dari wawancara yang dilakukan.

Dalam bidang pengembangan ekonomi masyarakat, PT. Pertamina (Persero) RU II Dumai dalam menjalankan program kemitraan yang sesuai dengan amanat Undang-Undang tetap menerapkan sistem bunga dalam memberikan pinjaman kepada masyarakat. Hal ini sesuai dengan hasil wawancara penulis bersama Bapak Tengku Muhammad Rum yang menjabat sebagai Jr. Officer CSR RU II Pertamina (Persero) RU II Dumai sebagai berikut:

"Pertamina Dumai dalam memberikan bantuan kepada masyarakat dalam upaya pengembangan ekonomi masyarakat tetap menerapkan sistem bunga hingga 5\%. Namun bunga tersebut tetap dikembalikan kepada masyarakat untuk realisasi CSR tahun berikutnya. Sehingga dana tersebut tetap dikembalikan kepada masyarakat"

Di sisi lain, distribusi pendapatan Pertamina Dumai belum mampu merealisasikan sesuai dengan kebutuhan dan keinginan masyarakat. Dalam ekonomi Islam, mekanisme alokasi dan distribusi pendapatan dan kekayaan berkaitan erat dengan nilai moral Islam sebagai alat untuk mengantarkan manusia pada kesejahteraan dunia akhirat. Bahwa kewajiban hamba kepada Tuhannya merupakan prioritas utama dari segala tindakan manusia yang menjadikan mekanisme distribusi pendapatan dan kekayaan yang bertujuan pada pemerataan menjadi sangat urgen pada perekonomian Islam. Karena diharapkan setiap manusia dapat menjalankan kewajibannya sebagai hamba Allah swt tanpa harus dihalangi oleh hambatan yang di luar kemampuannya.

Dalam melakukan operasionalnya, perusahaan wajib memperhitungkan dan memperhatikan tanggung jawab sosial perusahaan berdasarkan aspek kepatutan dan kewajaran. Islam memandang CSR sebagai sebuah konsep yang patut ditaati oleh setiap perusahaan sebagai akibat dari dampak yang ditimbulkan secara langsung maupun tidak langsung terhadap tatanan kehidupan sosial.

Pengaturan realisasi CSR yang baik dan benar bisa merujuk pada pola realisasi distribusi pendapatan dalam Islam. Islam mengajarkan umatnya untuk tidak hidup bermewah-mewahan dan saling berbagi dari pihak yang berkecukupan kepada pihak yang berkekurangan. Konsep yang paling mendominasi untuk diadobsi oleh realisasi CSR di dalam Islam adalah zakat. Baitul mal membagikan kepada orang yang membutuhkan untuk meringankan masalah hidup orang lain dengan cara memberi bantuan langsung ataupun tidak langsung. 
Pola-pola realisasi harta yang telah diajarkan oleh Islam memberikan dampak positif dalam mengatur tatanan kehidupan sosial. Dengan demikian untuk meningkatkan efektifitas realisasi CSR yang baik dan benar, maka perusahaanperusahaan baik swasta maupun BUMN yang ada di negeri ini sudah saatnya menerapkan sistem realisasi yang telah dicontohkan oleh konsep distribusi pendapatan dalam Islam.

Oleh sebab itu, berdasarkan hasil kuesioner realisasi CSR Pertamina Dumai sebuah tinjauan distribusi pendapatan dalam Islam tersebut, maka diperoleh ratarata variabel CSR untuk 12 pernyataan sebagai berikut:

Tabel 5: Rata-Rata Jawaban Responden

Variabel CSR

\begin{tabular}{|l|c|}
\hline \multicolumn{1}{|c|}{ Opsi Jawaban } & Rata-Rata \\
\hline \hline Sangat Setuju & 50,08 \\
\hline Setuju & 95,08 \\
\hline Cukup Setuju & 78,92 \\
\hline Tidak Setuju & 38,67 \\
\hline Sangat Tidak Setuju & 7,25 \\
\hline
\end{tabular}

Jika digambarkan dengan menggunakan grafik, maka akan terlihat seperti grafik berikut ini:

\section{Gambar 1: Rata-Rata Jawaban Responden Variabel CSR}

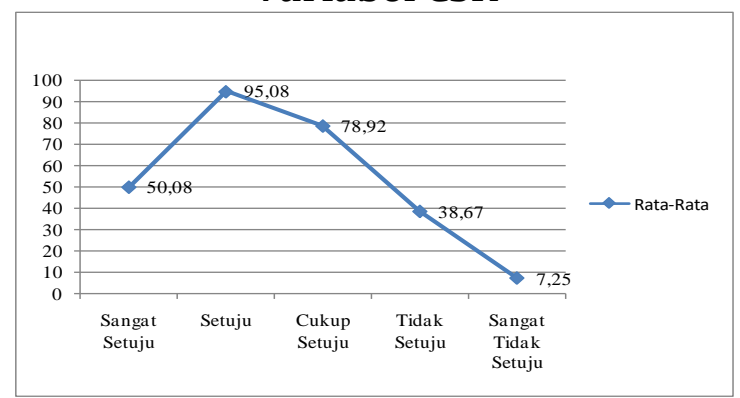

Sedangkan untuk variabel distribusi rata-rata variabelnya untuk 12 pernyataan pendapatan dalam Islam, maka diperoleh sebagai berikut:

Tabel 6: Rata-Rata Jawaban Responden Variabel Distribusi Pendapatan Dalam Islam 


\begin{tabular}{|l|c|}
\hline \multicolumn{1}{|c|}{ Opsi Jawaban } & Rata-Rata \\
\hline \hline Sangat Setuju & 39,67 \\
\hline Setuju & 78,33 \\
\hline Cukup Setuju & 94 \\
\hline Tidak Setuju & 48,83 \\
\hline Sangat Tidak Setuju & 9,17 \\
\hline
\end{tabular}

Dan jika digambarkan dengan menggunakan grafik, maka akan terlihat seperti grafik berikut ini:

Gambar 2: Rata-Rata Jawaban Responden Variabel Distribusi Pendapatan Dalam Islam

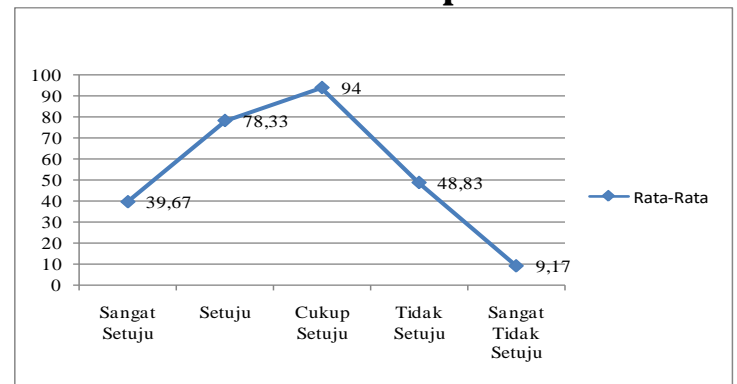

Dari tabel rata-rata variabel CSR dan variabel distribusi pendapatan dalam Islam yang telah dijelaskan tersebut, maka terlihat kecenderungan responden memberikan jawaban setuju. Artinya realisasi Pertamina Dumai periode 20112015 berdasarkan kuesioner yang telah disebarkan berdampak positif bagi kehidupan masyarakat sekitar, khususnya bagi kecamatan yang menjadi objek penelitian ini.

\section{SIMPULAN}

Berdasarkan analisa dan pembahasan, maka dapat disimpulkan beberapa hal penting yang berkaitan dengan realisasi Corporate Social Responsibility/ CSR PT. Pertamina (Persero) RU II Dumai dalam tinjauan distribusi pendapaatan dalam Islam sebagai berikut:

\section{Realisasi CSR Pertamina Dumai berdampak positif terhadap kehidupan masyarakat.}

Ini dibuktikan dari hasil kuesioner, wawancara serta dokumentasi data realisasi CSR Pertamina dari tahun 20112015 yang telah dilakukan. Berdasarkan hasil kuesioner dengan menggunakan 24 indikator, terbukti sebanyak 18 pernyataan masyarakat memberikan respon sangat setuju, setuju dan cukup setuju yang lebih besar. Sedangkan untuk 6 pernyataan lainnya dijawab dengan respon tidak setuju yang lebih besar.

Sementara itu, wawancara yang dilakukan bersama divisi CSR Pertamina dan tokoh masyarakat Dumai yang diwakili oleh Ketua Lembaga Adat Melayu Riau Kota Dumai serta Lurah di Kecamatan yang menjadi sampel penelitian ini memberikan respon bahwa sesungguhnya CSR Pertamina Dumai memang memberikan dampak positif bagi 
kehidupan masyarakat Dumai pada umumnya dan masyarakat yang menjadi sampel penelitian pada khususnya, namun belum terorganisir dengan baik. Sehingga perlu adanya perbaikan strategi, sosialisasi dan transparansi dari Pertamina Dumai itu sendiri.

2. Informasi-inforrmasi terkait dengan tanggung jawab sosial yang dilaksanakan oleh Pertamina Dumai periode 20112015 tidak sepenuhnya sesuai dengan konsep dan karakteristik realisasi CSR berdasarkan distribusi pendapatan dalam Islam dan masih membutuhkan beberapa perbaikan baik dari sisi teknis maupun acuan yang digunakan.

Ini dibuktikan dari hasil kuesioner dan wawancara yang telah dilakukan. Pemberian bantuan dana kepada masyarakat untuk pengembangan ekonomi masyarakat sebaiknya dilakukan evaluasi, karena sistem bunga yang digunakan tentunya tidak sesuai dengan konsep dan ajaran Islam. Oleh sebab itu, perlu dilakukan perbaikan teknis agar realisasi CSR Pertamina Dumai sepenuhnya sesuai dengan ajaran Islam dan sesuai dengan konsep distribusi pendapatan dalam Islam.

\section{DAFTAR RUJUKAN}

Akhmad Mujahidin, "Ekonomi Islam; Sejarah, Konsep, Instrumen, Negara dan Pasar", Jakarta: PT. RajaGrafindo Persada, 2014, 2014

Akhmad Mujahidin, "Ekonomi Islam 2 (Pasar, Perdagangan, Manajemen, Produksi, Konsumsi, Institusi Keuangan dan Kontribusi)", (Pekanbaru: Al-Mujtahadah Press, 2014

Darmawati, "Corporate Social Responsibility Dalam Perspektif Islam", Jurnal, Mazahib, Vol. XIII, No. 2, Desember 2014.

M. Faroid dan Kholid Murtadlo, "Pengaruh Penetapan CSR terhadap Citra Perusahaan PT. Tirta Investama Kebon Candi pada Masyarakat Desa. 